\section{Notaire}

Vol. 2 No. 1, Februari 2019
e-ISSN: 2655-9404

DOI: $10.20473 /$ ntr.v2i1.12986

Article history: Submitted 13 December 2018 ; Accepted 7 January 2019; Available online 1 February 2019.

\title{
Proportionality Principle On Online Lending Contract in Indonesia
}

\author{
Chesa Ramadhan and Adimas R. Saksono \\ Chesaramadhan021095@gmail.com \\ Universitas Airlangga
}

\begin{abstract}
Online lending is form of alternative funding resulted from financial technology innovation. Until February 2019 there are 99 financial technology corporations that engaged in lending activity that operated officially, legally, and recognized by Otoritas Jasa Keuangan. However, many problems arise form this innovation in form of online lending. Many consumers became the victims of either illegal or even legal online lending platforms. Started from the paramount loan interest applied in the online lending agreement until the amount of loan that need to be paid did not in accordance to the initial amount of debt, become core of the problems for the online lending consumers that treated unfair and unjustly by the online lending platform organizer. Moreover, online lending contract commonly belonged to the standard clause agreement that have been pre-arranged by one of the contracting parties. This research has purpose to determine the urgency of application of the proportionality principle on online lending contract. This research using doctrinal research method followed by conceptual and statute approaches. This research expected to generates conclusion on the notions of application of proportionality principle on online lending contract that included as standard clause contract in order to distribute contracting parties' rights and obligations proportionally. Therefore, in future the online lending agreement could generate justice and proportional contract for contracting parties and the substance of the contract can reflect this proportionality principle.
\end{abstract}

Keywords: Online Lending Agreement; Proportionality principle; Standard Clause Agreement.

\begin{abstract}
Abstrak
Pinjaman online merupakan bentuk dari alternatif pendanaan yang merupakan hasil dari inovasi teknologi finansial. Hingga bulan Februari 2019 terdapat 99 perusahaan teknologi finansial pinjammeminjam yang telah beroperasi secara resmi, terdaftar dan diakui oleh Otoritas Jasa Keuangan. Namun, inovasi berupa pinjaman online ini bukannya tanpa masalah. Masih banyak konsumen dari pinjaman online baik yang belum beroperasi secara resmi atau bahkan telah beroperasi secara resmi, terdaftar dan diakui oleh Otoritas Jasa Keuangan yang menjadi korban dari ketidakadilan penyelenggara pinjaman online. Mulai dari tingginya bunga yang ditetapkan, hingga jumlah hutang yang harus dibayarkan yang tidak sesuai dengan tagihan awal yang diberikan menjadi pokok permasalah bagi para konsumen pinjaman online yang merasa dirugikan. Terlebih lagi, perjanjian pinjaman online ini merupakan jenis perjanjian dengan klausula standard yang bentuknya telah ditentukan sebelumnya. Penelitian ini bertujuan untuk menentukan urgensi dari penerapan asas proporsionalitas dalam perjanjian pinjaman online. Penelitian ini menggunakan metode penelitian hukum doktrinal, dengan pendekatan undang-undang dan konseptual. Penelitian ini diharapkan menghasilkan suatu gagasan bahwa dalam perjanjian pinjaman online yang merupakan perjanjian dengan klausula standar, diperlukan diterapkannya asas proportionalitas yang bertujuan untuk membagi hak dan kewajiban para pihak secara proporsional. Hal ini bertujuan agar perjanjian pinjaman online yang dimaksud ini dapat membawa keadilan dan proporsionalitas bagi para pihak. Asas proporsionalitas ini selanjutnya diterapkan dalam beberapa klausa yang ada dalam perjanjian pinjam meminjam online ini agar mencerminkan suatu perjanjian yang adil dan proporsional.
\end{abstract}

Kata Kunci: Perjanjian Pinjaman Online; Prinsip Proporsionalitas; Perjanjian Klausa Standar. 


\section{Introduction}

Online lending service provides convenience of obtaining fund for party in need (further mentioned as borrower). In order to obtain fund from the lender, borrower only required to fulfil fewer and easier requirements compared to obtaining loan from Bank. This convenience meant higher risk for the lender; therefore, in order to give assurance for lender, organizer of online lending established higher loan interest compared to the loan interest offered by Bank. ${ }^{1}$ In 2019 Conventional bank offer loan interest around $8-14 \%$ per annum, ${ }^{2}$ compared to that online lending platform offer loan interest around $20 \%$ or more per annum. ${ }^{3}$ Although, Indonesian government regulates online lending through OJK regulation of Number 77/POJK.01/Year 2016 (further mentioned as POJK 77/2016), but this regulation didn't consist any article that regulates loan interest. Moreover, online lending contract as the legal basis of the online lending itself arranged only by organizer on behalf of lender without any participation of borrower, commonly called as standard clause contract. These conditions initiate problems for the legality of online lending contract itself as this violate some requirements of legality of contract based on Article 1320 Burgerlijk Wetboek (further mentioned as BW) and it will give more burden to one of the involved parties', which is borrower.

Based on those issues mentioned before, there are two legal issues that will be discussed in this paper. First, importance usage of proportionality principle in online lending contract; and second, the application of proportionality principle in online lending contract. This research is legal research as it analyses existing legal issues using legal research method. Research method used in this research is Doctrinal Research as stated by Terry Hutchinson and cited by Peter Mahmud Marzuki, as

1 Miriam Segal, 'Peer-to-Peer Lending: A Financing Alternative for Small Business' (10 SBA Office of Advocacy Issue, 2015) < https://www.sba.gov/sites/default/files/advocacy/Issue-Brief10-P2P-Lending_0.pdf $>$ accessed 1 January 2019.

2 Otoritas Jasa Keuangan, 'Suku Bunga Dasar Kredit (SBDK) Data Posisi Akhir Februari 2019’ (Otoritas Jasa Keuangan, 2019) < https://www.ojk.go.id/id/kanal/perbankan/Pages/SukuBunga-Dasar.aspx $>$ accessed 24 March 2019.

3 Investree, 'Interest Rates and Fees' (Investree, 2018) <https://www.investree.id/how-itworks/interest-rate-fee> accessed 24 March 2019. 
type of research that give systematic explanation towards certain regulation that regulate certain legal category, analyse relation between regulation, explain are that hindered, and perhaps, predicts future development. ${ }^{4}$

\section{Urgency of Proportionality Principle on Online Lending}

Development of technology and information has become part of our life, evolving our way of life including but not limited to: social, communication, and economic sphere. One of the spheres that affected significantly by the development of technology and information is finance, as it commonly mentioned as Financial Technology (further abbreviated and mentioned as fintech). Fintech is a form of financial service industry based on information technology, which the information technology itself has huge role on its development and application. ${ }^{5}$ Fintech has several purposes, one of them are increasing the accessibility of fintech, thus it capable to serves broader range of access compared to conventional financial industry.6 Fintech had produced many innovations, one of them are online lending service that currently popular in Indonesia. ${ }^{7}$

In common terms, online lending service also known as debt-based crowdfunding or peer-to-peer lending (further abbreviated and mentioned as P2P Lending). The first term derived from the understanding that general purpose of online lending service is similar to the crowdfunding, which is to collect funds from several parties and lend it to the other party in need. ${ }^{8}$ Crowdfunding itself divided into four categories based on the methods of fund collection, those are: ${ }^{9}$ donation-

4 Peter Mahmud Marzuki, Penelitian Hukum (Prenadamedia Group 2005).[32].

5 Patrick Schüffel, 'Taming the Beast: A Scientific Definition of Fintech' (2016) 4 Journal of Innovation Management.

6 ibid.

7 Lenny Sanicola, 'What Is Fintech?” (Huffington Post, 2017) < https://www.huffingtonpost. com/entry/what-is-Fintech_us_58a20d80e4b0cd37efcfebaa $>$ accessed 28 August 2018.

8 Nibusinessinfo.co.uk, 'Guide Crowdfunding' (Invest Northern Ireland, 2019) <https:// www.nibusinessinfo.co.uk/content/types-crowdfunding> accessed 1 August 2018.

9 ibid. 
based crowdfunding, ${ }^{10}$ reward-based crowdfunding, equity-based crowdfunding, and debt-based crowdfunding. For the second term, it came from the subject of the contract itself on the narrower meaning, which is commonly participated by people or peer, either as party whose receives fund or party whose gives fund. However, both of these terms aren't applicable in Indonesian law, as Indonesian government through one of its institution that is Otoritas Jasa Keuangan (further abbreviated and mentioned as OJK) redefined online lending as "Layanan Pinjam Meminjam Uang Berbasis Teknologi Informasi" (further abbreviated and mentioned as LPMUBTI).

LPMUBTI regulated on POJK 77/2016 titled "Layanan Pinjam Meminjam Uang Berbasis Teknologi Informasi”. According to POJK 77/2016 Article 1 Paragraph 3, LPMUBTI defined as financial service that provides meeting between pemberi pinjaman or borrower with penerima pinjaman or lender in order to arrange the lending contract in Rupiah, directly, using electronic system through internet. However, word 'directly' that has been mentioned before don't mean in a literal way; instead, the meeting between borrower and lender arranged by LPMUBTI organizer (further mentioned as organizer) as the intermediary between both parties.

Organizer itself defined in POJK 77/2016 on Article 1 Paragraph 6 as Indonesian legal entity that provide, manage and operate the LPMUBTI. Organizer uses their website as the medium to provide, manage and operate the LPMUBTI also this website became place where the borrower and lender met. ${ }^{11}$ In order to become lender and borrower of online lending contract, the parties should become the member of the aforementioned website through registration, and this process continues with: ${ }^{12}$ First, parties need to fulfill requirements in order to able involve in online lending contract as borrower or lender; Second, for borrower, based on data given in requirement fulfilment, organizer will decide the capability of the

\footnotetext{
${ }^{10}$ Angel Investment Network Indonesia (ANGIN), 'Social Finance Landscape in Indonesia: A New Frontier for Development in Indonesia' (Report for UNDP Indonesia, 2016) <https:// ojk.go.id/sustainable-finance/id/publikasi/riset-dan-statistik/Documents/SF Report 2 ANGIN.pdf\#search $=$ ANGIN $>$ accessed 28 October 2018.

${ }^{11}$ cf Segal (n 2).

${ }^{12}$ Investree, 'Bagaimana Cara Kerja Peer-to-Peer Lending?' (Investree) $<$ https://www.investree.id/how-it-works> accessed 10 November 2018.
} 
borrower to repay the loan through credit rating, the higher credit rating given by the organizer will resulted in lower amount of loan interest and vice versa; Third, after this borrower will decide amount of the loan they needed and post it in the website in order to be funded by the lender; Fourth, after loan proposal posted in the website, lender will be able to decide which loan proposal they will fund and decide the amount of fund loaned; Fifth, if the loan proposal fully funded, organizer will finalized the loan proposal, and if it finalized lender will be asked to sign power of attorney agreement with organizer. This agreement needed because in online lending contract it is possible there are more than one lender involved in the contract; thus, it is more convenience if organizer represent lender collectively; Sixth, both parties will be asked to sign an online lending contract made by the organizer as a form of agreement for the online funding process that has been agreed before; Seventh, the funds that have been loan to the borrower will be transferred to escrow account, and this account will be used in all transaction performed in this contract, including receiving borrower's repayment of loan with loan interest and transferring the repayment with loan interest to the lenders.

The online lending contract is integral part of the online lending process; therefore, the legal implication of this contract is important to be noticed, especially for the borrower. In Indonesia many cases of online lending resulted from the incapability of the borrower to repay the debt they had, which resulted in inhuman collection of debt. ${ }^{13}$ If inspecting to the root of these problems, it actually came from the methods of online lending contract arrangement that have been pre-arranged only by organizer on behalf of the lender without involving borrower. This kind of contract also can be called as standard form contract that defined by Black's Law Dictionary as "pre-printed contract containing set clauses, used repeatedly by a business or within a particular industry with only slight of changes to meet specific purposes $" .{ }^{14}$

13 'BBC, 'Pinjaman Online Dan Penyebaran Data Nasabah: Aksi 'rentenir Digital' (BBC, 2019) <https://www.bbc.com/indonesia/trensosial-46107193> accessed 25 March 2019 ..

14 Bryan A. Garner, Black's Law Dictionary (9th edn, West Publishing 2009). [325]. 
Standard form contract could be included as adhesion contract, which defined by Black's Law Dictionary as “standard-form of contract that prepared by one party, to be signed by the party in weaker position, i.e. a consumer, who has little choice about the terms included in contract. Also termed contract of adhesion; take it-orleave it contract". ${ }^{15}$ Not all standard form of contract classified as adhesion contract; however, this type of standard form contract is the main discussion related to the urgency of proportionality principle in online lending.

Ahmad Fikri Assegaf stated that adhesion contract commonly has tendency to be lopsided, usually caused by party weakness in bargaining position, ignorance, or indifference, and in the end unfavoured parties are willing to enter into contract controlled by these lopsided legal documents. ${ }^{16}$ This unequal bargaining position in contract would violates the equality principle that stated by several academics. Equality principle generally defined as the equal position of contracting parties, if there is inequality in contract that disturb contract's substances; therefore, it requires intervention from some authorities i.e. government. ${ }^{17}$

Herlien Budiono stated that equality principle in contract is needed to provide equality if there is inequality in contract; as the purpose of this principle is about the final result to make sure that both parties are in the equal position in determining their contract's rights and obligations. ${ }^{18}$ Government intervention to make sure parties have equal position in contract is pictured in Law Number 8 Year 1999 on Consumer Protection, Article 18 that regulate the standard clause in contract. This article stated that business actor should make sure that standard clause included in contract don't harm the consumers. Article 62 (1) further implied, business actor that still included standard clause that harm consumers could be punished with imprisonment or fine.

\footnotetext{
15 ibid.[319].

${ }^{16}$ Ahmad Fikri Assegaf, Penjelasan Hukum Tentang Klausula Baku (Pusat Studi Hukum dan Kebijakan Indonesia 2014).[30].

${ }^{17}$ Agus Yudha Hernoko, Hukum Perjanjian: Asas Proporionalitas Dalam Kontrak Komersial (Kencana 2010).[79].

${ }^{18}$ Herlien Budiono, Ajaran Umum Hukum Perjanjian Dan Penerapannya Di Bidang Kenotariatan (Citra Aditya Bakti 2014).[32].
} 
Equality principle still felt abstract to be applied in contract (in this case online lending contract). This principle merely focused on the equal position of contracting parties and expect the result for them will be fair and just. However, equality principle should not only focus on giving equal position for both contracting parties, because contracting process should be seen as a whole process. There are also other phases, such as pre-contractual phase (preparation), contractual (arrangement and finalization) and post-contractual (execution and consequences). Therefore, there should be another principle to complement this imperfect principle.

Related to the imperfection of equality principle of contract, there is another known principle named proportionality principle of contract. Agus Yudha Hernoko stated that proportionality principle is more dominance on commercial contract and this principle imply on the exchange of rights and obligation that fair and just. ${ }^{19}$ In this principle, it must be recognized that there've been always inequality of position between parties and it is unavoidable; thus, when this inequal parties involved in contract, the inequality shouldn't utilized by dominant parties to assert their will and/or interests to the other parties. ${ }^{20}$

Based on those statements, the proportionality principle is embodiment of contractual justice that corrected the freedom of contract principle that could raised unjust situation for the parties in contract. ${ }^{21}$ It also emphasized that freedom of contract is not the main principle on the contract arrangement, but it should emphasize the contractual justice instead. Proportionality contract become the basis exchange of parties' rights and obligations corresponding to their proportion in overall contractual relation process (pre-contractual, contractual, post-contractual) to make sure conducive and fair correlation between parties. Based on this Agus Yudha Hernoko further imply the criteria that should become guidance to discover proportionality principle in contract: ${ }^{22}$

\footnotetext{
19 Agus Yudha Hernoko (n 17). Op.Cit. [84].

20 ibid.[87].

${ }^{21}$ ibid.[87].

${ }^{22}$ Agus Yudha Hernoko, 'The Principle of Proportionality as The Basis Exchange Rights and Obligations of The Parties In the Commercial Contract' (2016) 5 Hukum dan Peradilan.[447] dan [459].
} 
a. Contract with proportionality principle means a contract that grants recognition towards parties of the contract equal right, opportunity and chance. It is not about the equal result for parties; however, it implies on the position of parties to obtain rights and obligation equitability;

b. Based on the equal rights mentioned before, parties have freedom to construct contract and decide which contract's substances that fair and unfair to them;

c. Capable to guarantee right execution and proportional rights distribution for both parties at once. In this case, the final result for both parties could be different, thus the exchange of parties' rights and obligation should be fair; and

d. If there is contract dispute, burden of proof, distribution of fault, or any related matters should be measured based on proportionality principle in order to achieve elegant resolution and win-win solution.

Based on this, contract constituted chain process of contracting parties' correlation that must be constructed based on understanding of just based on recognition of contracting parties' rights. This recognition manifested on the equal distribution of opportunity on exchange of rights and obligation; however, this must be still in frame of rules that consider principle of proportional distribution. ${ }^{23}$

Related to the online lending contract, it is allowed for the contract in form of standard clause contract that have been pre-arranged only by the organizer on behalf of the lender as stated in Article 18 Law Number 8 Year 1999 on Consumer Protection; however, this type of contract shall not categorized into adhesion contract that lopsided only to one party. Nevertheless, in the reality online lending contract tends to be lopsided and give more burden to the borrower; therefore, the proportionality principle presents to make sure that online lending contract is fair and just. Even though, the online lending contract pre-arranged only by one of the contracting parties, the substance contained within this contract should reflect and give equal distribution of opportunity on exchange of rights and obligation toward both contracting parties. It is true that inequality between contracting parties is unavoidable; however, contracting parties should realize that each of them have to obtain rights and obligation proportionally; thus, it will be resulting in online lending contract that benefitting both contracting parties.

${ }^{23}$ ibid.[460]. 


\section{Application of Proportionality Principle in Online Lending Contract}

It is true that proportionality principle should be applied on standard clause contract such as online lending contract. The question arises regarding the methods to apply the proportionality principle in online contract. Online lending contract included into the standard clause contract based on the reason that this contract has been pre-arranged by one of the contracting parties and other party only need to agreed or not to the contract. For the pre-arranged contract, only one party that involved in the arrangement of contract, meaning that other party don't have any chance in arrange the substance of contract. Proportionality principle emphasized the overall contractual relation process (pre-contractual, contractual, post-contractual) to make sure conducive and fair correlation between parties; thus, application of proportionality principle will be hindered if only one party involved in contract arrangement the process. That's why in contract arrangement (contractual) phase of the online lending contract, it requires government intervention to "replace" unoccupied position left by the lender that not included in the arrangement phase.

Problems of the online lending process came from the high loan interest applied in the contract. This higher loan interest compared to conventional bank was resulted from the online lending as unsecured loan. Conventional bank provides more requirements for the borrower in order to be able to receives loan, unlike the organizer of LPMUBTI that able to provides loan to borrower even without any collateral. ${ }^{24}$ However, the risk of this type of loan is when the borrower incapable to repay their debt to the lender; therefore, the lender will not able to collect the debt other than directly collect to the borrower. In the other hand, borrower don't have any recourse to repay their debt if they incapable to repay it by their own. Incapability of borrower to repay their debt also resulting in collection of debt by lender that usually utilized third parties, such as loan sharks to collect their debt. Therefore, based on the problems presented before, there are about three matters

\footnotetext{
${ }^{24}$ Cermati.com, 'Pinjaman Tanpa Jaminan: Syarat-Syarat Yang Mesti Diketahui' (Cermati. com, 2016) <https://www.cermati.com/artikel/pinjaman-tanpa-jaminan-syarat-syarat-yang-mesti-diketahui $>$ accessed 26 April 2019.
} 
that required government interference, those are related to: amount of loan interest on the online lending contract; and obligation for borrower to include recourse on the online lending contract.

Based on the POJK 77/2016 on LPMUBTI, there aren't any article that regulates on the minimum or maximum amount cap of loan interest apply in the online lending agreement. Lending in general allowed loan interest as stated by Article 1765 BW. However, BW on Article 1339 also imply regarding the propriety, customs, and law. In regard of the maximum or minimum cap of loan interest, POJK $77 / 2016$ on LPMUBTI didn't regulate any of those subjects. However, the amount of loan interest could be determined based on the conventional bank interest rate, for example: if conventional bank determined loan interest on $8-14 \%$, organizer should apply loan interest close to those amounts. In present, online lending loan interest could reaching $40 \%$ if the borrower's credit rating deemed risky by the organizer. It is known that organizer in the end will bear the burden if the borrower fails to repay the debt; however, based on the proportionality principle, there should be fair distribution of burden among contracting parties. ${ }^{25}$

Higher loan interest in online lending also caused by the situation of no recourse lending, which bear higher burden on the organizer and lender. This risk, can be minimized by requiring the borrower to provide collateral to mitigate the risk used to bear by the lender and organizer in the non-recourse online lending. If this requirement argued by scholar for deviating the basic principle and purpose of online lending to have loan without recourse. This argument can be answered through Article 1820 BW on debt underwriting. Debt underwriting can become alternative to the provider of collateral that commonly used in loan contract. There are three types of subject in debt underwriting, those are: Individual, Corporation, and Bank. ${ }^{26}$ Debt underwriting must be agreed by the subject of debt underwriting. In practice, this agreement will be in form of debt underwriting agreement divided

\footnotetext{
${ }^{25}$ Agus Yudha Hernoko (n 22).Loc.Cit.[459].

${ }^{26}$ Irma Devita Purnamasari, Kiat-Kiat Cerdas, Mudah, Dan Bijak Memahami Masalah Hukum Jaminan Perbankan (2014) <Mizan Media Utama>.[151].
} 
based on the subject of the debt underwriting, namely: Personal guarantee or Borgtocht; Corporate guarantee; and Bank guarantee.

These distributions of risk that have been suggested before threatened to be hindered because online lending contract used standard clause contract that have been pre-arranged before. However, government capable to intervene this unproportioned distribution of risk by providing regulation that regulates loan interest limit for the online lending contract. POJK 77/2016 as sole regulation that regulates LPMUBTI proved not enough to regulate online lending, as there are still a lot more things that need to be regulated under POJK. Therefore, it is suggestion for the government of Indonesia to legislate more OJK regulation/POJK that covers more subject that still untouched by the current regulation.

\section{Conclusion}

Freedom of contract principle sometimes could generate lopsided contract that will generate lopsided burden towards contracting parties, especially online lending contract that commonly pre-arranged by one of the contracting parties without involving the other parties. Therefore, there is urgency to apply the proportionality principle in order to distribute contracting parties' exchange of right and obligation proportionally throughout overall process of contract (pre-contractual, contractual, and post-contractual). Proportionality principle will generate just and proportional contract; although there is inequal bargaining position of the contracting parties. Application of the proportionality principle in online lending contract can be applied related to the loan interest and recourse clause, because these two clauses is the core problems of the online lending contract that generates lopsided burden towards one of the parties. However, as this contract included as standard clause contract and only arranged by one party and not involving others; therefore, this application of proportionality principle could be conducted through government regulation in form of POJK or OJK regulation that will covers more subject that used to be unregulated, especially on loan interest cap and obligation to enclose recourse. 


\section{Bibliography}

\section{Books}

Agus Yudha Hernoko, Hukum Perjanjian: Asas Proporionalitas Dalam Kontrak Komersial (Kencana 2010).

Ahmad Fikri Assegaf, Penjelasan Hukum Tentang Klausula Baku (Pusat Studi Hukum dan Kebijakan Indonesia 2014).

Bryan A. Garner, Black’s Law Dictionary (9th edn, West Publishing 2009).

Herlien Budiono, Ajaran Umum Hukum Perjanjian Dan Penerapannya Di Bidang Kenotariatan (Citra Aditya Bakti 2014).

Irma Devita Purnamasari, Kiat-Kiat Cerdas, Mudah, Dan Bijak Memahami Masalah Hukum Jaminan Perbankan (Mizan Media Utama 2014).

Peter Mahmud Marzuki, Penelitian Hukum (Prenadamedia Group 2005).

\section{Journal}

Agus Yudha Hernoko, 'The Principle of Proportionality as The Basis Exchange Rights and Obligations of The Parties In the Commercial Contract' Hukum dan Peradilan (2016).

Miriam Segal, 'Peer-to-Peer Lending: A Financing Alternative for Small Business' (10 SBA Office of Advocacy Issue, 2015).

Patrick Schüffel, 'Taming the Beast: A Scientific Definition of Fintech' (2016) 4 Journal of Innovation Management.

\section{Regulations}

Otoritas Jasa Keuangan, 'Suku Bunga Dasar Kredit (SBDK) Data Posisi Akhir Februari 2019' (Otoritas Jasa Keuangan, 2019) < https://www.ojk.go.id/id/ kanal/perbankan/Pages/Suku-Bunga-Dasar.aspx > accessed 24 March 2019.

\section{Internet}

Angel Investment Network Indonesia (ANGIN), 'Social Finance Landscape in Indonesia: A New Frontier for Development in Indonesia' (Report for UNDP Indonesia, 2016) <https://ojk.go.id/sustainable-finance/id/publikasi/risetdan-statistik/Documents/SF Report 2 ANGIN.pdf\#search=ANGIN $>$ accessed 28 October 2018. 
BBC, 'Pinjaman Online Dan Penyebaran Data Nasabah: Aksi 'rentenir Digital' (BBC, 2019) <https://www.bbc.com/indonesia/trensosial-46107193> accessed 25 March 2019.

Cermati.com, 'Pinjaman Tanpa Jaminan: Syarat-Syarat Yang Mesti Diketahui' (Cermati.com, 2016) <https://www.cermati.com/artikel/pinjaman-tanpajaminan-syarat-syarat-yang-mesti-diketahui> accessed 26 April 2019.

Investree, 'Bagaimana Cara Kerja Peer-to-Peer Lending?' (Investree) <https:// www.investree.id/how-it-works> accessed 10 November 2018.

Investree, 'Interest Rates and Fees' (Investree, 2018) < https://www.investree.id/ how-it-works/interest-rate-fee> accessed 24 March 2019.

Lenny Sanicola, 'What Is Fintech?" (Huffington Post, 2017). $<$ https://www. huffingtonpost.com/entry/what-is-Fintech_us_58a20d80e4b0cd37efcfebaa $>$ accessed 28 August 2018.

Nibusinessinfo.co.uk, 'Guide Crowdfunding' (Invest Northern Ireland, 2019) $<$ https://www.nibusinessinfo.co.uk/content/types-crowdfunding $>$ accessed 1 August 2018.

HOW TO CITE: Chesa Ramadhan and Adimas R. Saksono, 'Proportionality Principle on Online Lending Contract in Indonesia' (2019) Vol. 2 No. 1 Notaire. 
--halaman ini sengaja dibiarkan kosong-- 